\title{
NEW STABILITY-INDICATING ULTRA PERFORMANCE LIQUID CHROMATOGRAPHY METHOD DEVELOPMENT AND VALIDATION OF LENVATINIB MESYLATE IN BULK DRUG AND PHARMACEUTICAL DOSAGE FORMS
}

\author{
JAHNAVI BANDLA ${ }^{1 *}$, S. GANAPATY ${ }^{2}$ \\ ${ }^{1}$ Department of Pharmaceutical Analysis and QA, Faculty of Pharmacy, Vishnu Institute of Pharmaceutical Education and Research, \\ Narsapur, Medak, Telangana, India. ${ }^{2}$ Department of Pharmacognosy and Phytochemistry, GITAM Institute of Pharmacy GITAM University, \\ Rushikonda, Visakhapatnam, Andhra Pradesh, India. Email: Jahnavi.bandla@gmail.com
}

Received: 17 May 2018, Revised and Accepted: 9 June 2018

ABSTRACT

Objective: The objective of the present study was to develop and validate a new stability-indicating method for the quantification of lenvatinib mesylate in bulk drug and pharmaceutical dosage form using ultra performance liquid chromatography (UPLC).

Methods: The optimized chromatographic conditions for elution of drug included UPLC HSS C18 (100 mm $\times 2.1 \mathrm{~mm}, 1.8 \mathrm{~m})$ column, mixture of $0.1 \%$ orthophosphoric acid and acetonitrile $(50: 50 \mathrm{v} / \mathrm{v} \%)$ mobile phase run on an isocratic mode at a flow rate of $0.3 \mathrm{~mL} / \mathrm{min}, 240 \mathrm{~nm}$ detection wavelength, and column oven temperature maintained at $30^{\circ} \mathrm{C}$.

Results: The retention time for lenvatinib was found to be $1.24 \mathrm{~min}$. The developed method was validated for various validation parameters in accordance with the International Conference on Harmonization guidelines. The method obeyed Beer's law in the concentration range of 2.5$15 \mu \mathrm{g} / \mathrm{mL}$ with a correlation coefficient of 0.9996 . The percentage relative standard deviation and percentage recovery were determined to be 0.4 and 99.66-100.30\%, respectively. The developed method was found to be accurate, precise, specific, linear, rugged, and robust. Forced degradation studies were conducted by exposing the drug to diverse stress conditions such as acidic, basic, peroxide, neutral, photolytic, and thermal conditions. The net degradation was obtained within the limits.

Conclusion: The developed method for the estimation of lenvatinib can be employed to routine analysis of pharmaceutical dosage form.

Keywords: Lenvatinib mesylate, Ultra performance liquid chromatography, Stability indicating, Method development, Validation.

(c) 2018 The Authors. Published by Innovare Academic Sciences Pvt Ltd. This is an open access article under the CC BY license (http://creativecommons. org/licenses/by/4. 0/) DOI: http://dx.doi.org/10.22159/ajpcr.2018.v11i9.26766

\section{INTRODUCTION}

Lenvatinib mesylate (Fig. 1) [1,2] chemically known as 4-[3-chloro-4( $\mathrm{N}^{\prime}$-cyclopropylureido)phenoxy]-7-methoxyquinoline-6-carboxamide methanesulfonate. It is a white to pale reddish-yellow powder, slightly soluble in water and practically insoluble in ethanol. It is a pKa value of 5.05. It belongs to anticancer category and utilized for the treatment of various kinds of thyroid cancer [3,4]. It acts as receptor tyrosine kinase inhibitor that inhibits the kinase activities of vascular endothelial growth factor receptors [5]. It also inhibits other RKTs that have been implicated in pathogenic angiogenesis, tumor growth, and cancer progression in addition to their normal cellular functions, including fibroblast growth factor receptors.

Ultra performance liquid chromatography (UPLC) [6-8] is a relatively new technique giving new possibilities in liquid chromatography, especially concerning the decrease of time and solvent consumption. UPLC chromatographic system is designed in a special way to withstand extreme system back pressures.

In accordance to literature review, it was known that there were only few methods such as reverse-phase high-performance liquid chromatography (RP-HPLC) [9-11], ultraviolet (UV) spectroscopy [11], and liquid chromatography coupled with tandem mass spectrometry method [12-14] developed for the estimation of lenvatinib.

As there was no UPLC method developed for the estimation of lenvatinib, the present study was intended to develop and validate a stability-indicating UPLC method for the quantitative determination of lenvatinib in bulk drug and pharmaceutical dosage form.

\section{METHODS}

\section{Chemicals and reagents}

Lenvatinib mesylate working standard was supplied as a gift sample from Spectrum Labs, Hyderabad. Lenvima capsules were purchased from a local pharmacy. All the chemicals used for the development of the method were of AR grade purchased from Merck, Mumbai. All the solvents used were of HPLC grade purchased from Sigma-Aldrich, Mumbai.

\section{Analytical conditions and instruments}

The ACQUITY UPLC system equipped with binary solvent manager, sample manager, UV detector, and UPLC HSS C18 $(100 \mathrm{~mm} \times 2.1 \mathrm{~mm}$, $1.8 \mu$ ) column was used for the determination of lenvatinib. The analytical conditions included $0.1 \%$ orthophosphoric acid and acetonitrile $(50: 50 \mathrm{v} / \mathrm{v} \%)$ as mobile phase run on an isocratic mode at a flow rate of $0.3 \mathrm{~mL} / \mathrm{min}$. The column was kept at $30^{\circ} \mathrm{C}$ and detection was done at $240 \mathrm{~nm}$ wavelength. Additional equipment included $\mathrm{pH}$ meter, ultrasonic bath sonicator, and weighing balance.

Preparation of mobile phase

Mixture of $0.1 \%$ aqueous orthophosphoric acid buffer and acetonitrile in the ratio of $50: 50 \mathrm{v} / \mathrm{v} \%$ was used as mobile phase.

Preparation of standard and sample solution

$10 \mathrm{mg}$ of lenvatinib working standard was dissolved in $100 \mathrm{ml}$ of diluent. $1 \mathrm{~mL}$ of the above standard stock solution was diluted to $10 \mathrm{~mL}$ diluent.

Average weight of 20 lenvima capsules was calculated and an amount equivalent to $10 \mathrm{mg}$ of lenvatinib was dissolved in $100 \mathrm{~mL}$ of diluent. 
The above sample stock solution was filtered and diluted 1-10 $\mathrm{mL}$ with diluent.

\section{Method validation}

The developed method was validated in compliance with the International Conference on Harmonization (ICH) guidelines [15] the following parameters are as follows:

\section{Accuracy}

Accuracy of the method was established by preparing three concentration levels of $50 \%, 100 \%$, and $150 \%$. Then, percentage recovery was calculated.

\section{Precision}

Precision of the method was determined by injecting six solutions of sample and then percentage relative standard deviation (RSD) was calculated.

\section{Specificity}

For the determination of specificity of the method, a placebo solution was prepared and compared with the drug solution for any interference of placebo peak with the drug peak.

\section{Linearity}

For the linearity study, serial dilutions of the drug solution were prepared in the concentration range of $2.50-15 \mu \mathrm{g} / \mathrm{mL}$. A graph was plotted by taking concentration on the $\mathrm{x}$-axis and peak area on y-axis.

\section{Limit of detection (LOD) and limit of quantitation (LOQ)}

LOD and LOQ are calculated using standard deviation and slope of the calibration curve by placing in the formula mentioned in the ICH guidelines.

\section{Ruggedness}

Ruggedness was evaluated by performing precision on different days and the percentage RSD was calculated.

\section{Robustness}

Robustness was determined by varying the optimized conditions such as variation of the organic phase in the mobile phase by $\pm 10 \%$, variation of flow rate by $\pm 0.1 \mathrm{~mL} / \mathrm{min}$, and variation of column oven temperature by $\pm 5^{\circ} \mathrm{C}$.

\section{Solution stability}

Solution stability was assessed by performing the assay of drug solutions after storing for $24 \mathrm{~h}$.

\section{Forced degradation studies}

Forced degradation studies [16] were conducted by exposing the drug solution to various degradation conditions such as acidic ( $2 \mathrm{~N}$ hydrochloric acid, $60^{\circ} \mathrm{C}$ for $30 \mathrm{~min}$ ), basic ( $2 \mathrm{~N}$ sodium hydroxide $[\mathrm{NaOH}], 60^{\circ} \mathrm{C}$ for $\left.30 \mathrm{~min}\right)$, oxidative $\left(20 \%\right.$ hydrogen peroxide $\left[\mathrm{H}_{2} \mathrm{O}_{2}\right]$, $60^{\circ} \mathrm{C}$ for $30 \mathrm{~min}$ ), neutral (refluxing the drug in water for $6 \mathrm{~h}, 60^{\circ} \mathrm{C}$ ), thermal $\left(105^{\circ} \mathrm{C}\right.$ for $6 \mathrm{~h}$ ), and photolytic (UV chamber for $7 \mathrm{~d}$ ) conditions. The net degradation for unusual conditions was noted.

\section{RESULTS}

\section{DISCUSSION}

For the development of a method for the estimation of lenvatinib, various mobile phases and stationary phases were tried to elute the drug with good peak parameters. The optimized conditions used were mobile phase consisting of composition $0.1 \%$ o-phosphoric acid and acetonitrile $(50: 50 \mathrm{v} / \mathrm{v} \%)$ run on an isocratic mode with flow rate of $0.3 \mathrm{~mL} / \mathrm{min}$, UPLC HSS C18 (100 mm $\times 2.1 \mathrm{~mm}, 1.8 \mathrm{~m})$ column maintained at $30^{\circ} \mathrm{C}$ temperature. Lenvatinib was detected at a wavelength of $240 \mathrm{~nm}$ as the drug shows maximum absorbance at that wavelength as shown in Fig. 2.
The standard solution, sample solution, and the blank solution were prepared as per the procedure mentioned above. The standard solution was injected into the UPLC system for evaluating the system suitability parameters. The results were presented in Table 1 and chromatograms were shown in Fig. 3.

The method was considered to be accurate as the percentage recovery for lenvatinib was found to be 99.66-100.30\%. The percentage RSD for lenvatinib was determined to be 0.4 , indicating that the method was precise. The developed method was found to be specific to the drug when compared with a placebo solution, as there was no interference

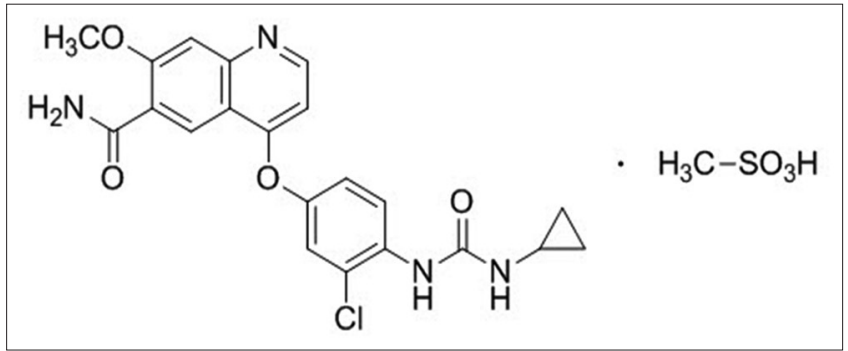

Fig. 1: Chemical structure of lenvatinib mesylate

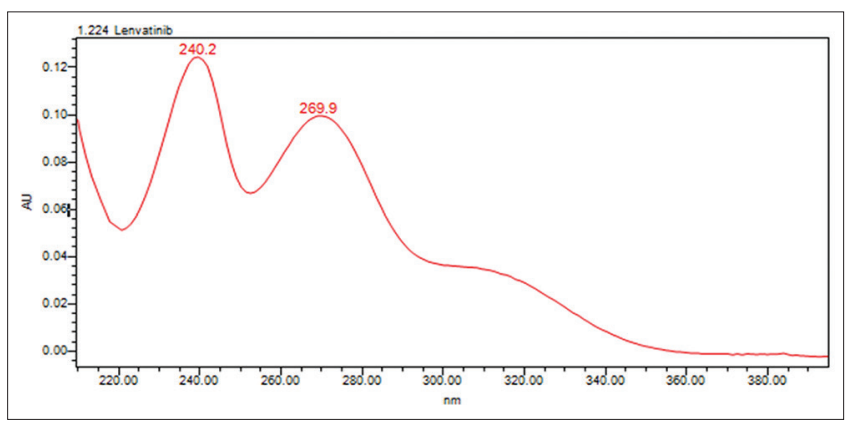

Fig. 2: Ultraviolet spectrum of lenvatinib

Table 1: Results of system suitability and validation parameters

\begin{tabular}{|c|c|c|}
\hline Parameter & Result & \\
\hline Precision (\%RSD, n) & 0.4 & \\
\hline Accuracy (\% Recovery, n) & $99.66 \%-100.30 \%$ & \\
\hline Specificity & $\begin{array}{l}\text { Specific, No } \\
\text { interference }\end{array}$ & \\
\hline Linearity range $(\mu \mathrm{g} / \mathrm{ml})$ & $2.5-15$ & \\
\hline Correlation coefficient, $\mathrm{r}$ & 0.9996 & \\
\hline $\begin{array}{l}\text { Limit of } \\
\text { detection (LOD) }(\mu \mathrm{g} / \mathrm{ml})\end{array}$ & 0.16 & \\
\hline $\begin{array}{l}\text { Limit of } \\
\text { quantitation (LOQ) } \\
(\mu \mathrm{g} / \mathrm{ml})\end{array}$ & 0.50 & \\
\hline \multirow[t]{2}{*}{ Ruggedness (\%RSD, n) } & Day 1 & Day 2 \\
\hline & 0.5 & 0.4 \\
\hline \multirow[t]{7}{*}{ Robustness (\%RSD, n) } & Less flow rate & More flow rate \\
\hline & 0.6 & 0.4 \\
\hline & $\begin{array}{l}\text { Less mobile } \\
\text { phase (organic) }\end{array}$ & $\begin{array}{l}\text { More mobile } \\
\text { phase (organic) }\end{array}$ \\
\hline & 0.7 & 0.5 \\
\hline & Less column & More column \\
\hline & temperature & temperature \\
\hline & 0.5 & 0.4 \\
\hline \multirow{3}{*}{$\begin{array}{l}\text { Solution } \\
\text { stability (\%RSD, n) }\end{array}$} & Day $1(0 \mathrm{~h})$ & Day 2 \\
\hline & & (After 24 h) \\
\hline & 0.5 & 0.4 \\
\hline USP plate count & 2422 & \\
\hline USP tailing factor & 1.16 & \\
\hline
\end{tabular}


Table 2: Results of forced degradation studies

\begin{tabular}{|c|c|c|c|}
\hline Stress condition & \% Assay & $\%$ Area of degradation peak & \% Degradation \\
\hline $2 \mathrm{~N} \mathrm{HCl}$ for $30 \mathrm{~min}$ at $60^{\circ} \mathrm{C}$ & 95.75 & - & 4.25 \\
\hline $2 \mathrm{~N} \mathrm{NaOH}$ for $30 \mathrm{~min}$ at $60^{\circ} \mathrm{C}$ & 95.71 & - & 4.29 \\
\hline $20 \% \mathrm{H}_{2} \mathrm{O}_{2}$ for $30 \mathrm{~min}$ at $60^{\circ} \mathrm{C}$ & 96.61 & - & 3.39 \\
\hline Water for $6 \mathrm{~h}$ at $60^{\circ} \mathrm{C}$ & 99.04 & - & 0.96 \\
\hline UV light $200 \mathrm{wts} / \mathrm{h}$ or $7 \mathrm{~d}$ & 97.27 & - & 2.73 \\
\hline $105^{\circ} \mathrm{C}$ for $6 \mathrm{~h}$ & 97.13 & - & 2.87 \\
\hline
\end{tabular}

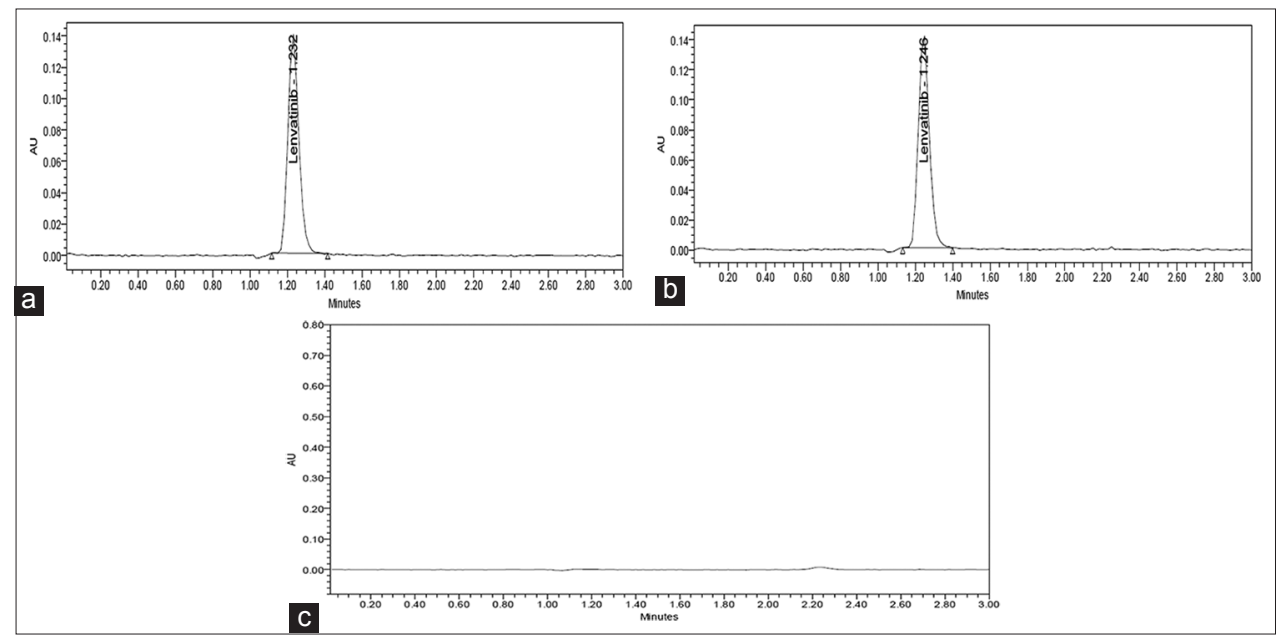

Fig. 3: (a) Ultra performance liquid chromatography (UPLC) chromatogram of lenvatinib standard solution, (b) UPLC chromatogram of lenvatinib sample solution, (c) UPLC chromatogram of blank solution

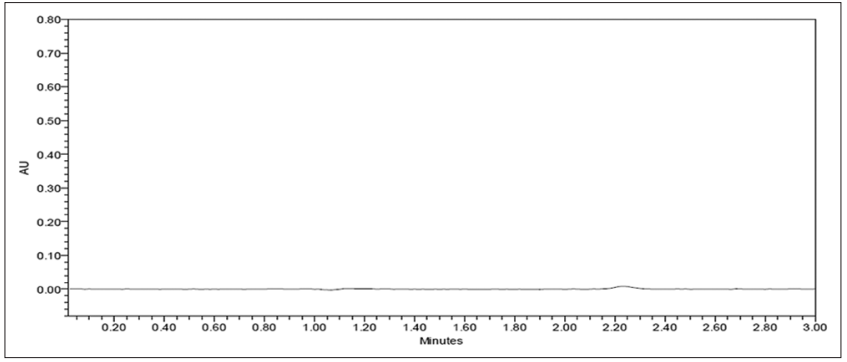

Fig. 4: Ultra performance liquid chromatography chromatogram of placebo solution

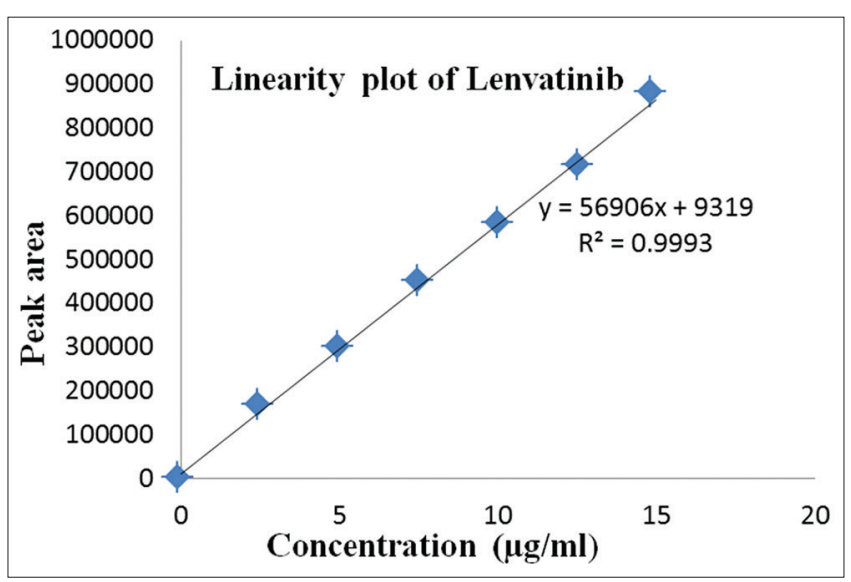

Fig. 5: Linearity plot of lenvatinib

of placebo peak with the drug peak. The placebo chromatogram was illustrated in Fig. 4.
The method was found to perform Beer's law in the concentration range of $2.5-15 \mu \mathrm{g} / \mathrm{mL}$ with a correlation coefficient of 0.9996 . The linearity plot was presented in Fig. 5.

The LOD and LOQ for lenvatinib were found to be $0.16 \mu \mathrm{g} / \mathrm{mL}$ and $0.50 \mu \mathrm{g} / \mathrm{mL}$, respectively. The method was found to be rugged as the percentage RSD when compared with day difference was found to be within the limits, robust when did by varying the optimized conditions and stable in solution form also after storing for $24 \mathrm{~h}$.

Forced degradation studies indicated that the samples remained stable under different stress conditions such as acidic, basic, oxidative, photolytic, and thermal conditions. The net degradation was considered to be within the limits. The results were outlined in Table 2 and chromatograms were shown in Fig. 6.

\section{CONCLUSION}

The new stability-indicating method was established for quantitative determination of lenvatinib in pharmaceutical dosage and bulk drug using UPLC. The developed method was validated in accordance with the ICH guidelines. The method was found to be accurate, precise, specific, linear, rugged, robust, and stable in solution. Forced degradation studies concluded that the drug was stable in various stress conditions.

This method can be applied to the routine analysis of lenvatinib in pharmaceutical dosage form.

\section{ACKNOWLEDGMENTS}

The authors are thankful to the Spectrum Labs, Hyderabad, for providing the lenvatinib as the gift samples and also for providing the required facilities to carry out this work.

\section{AUTHOR'S CONTRIBUTIONS}

All authors contributed equally to this manuscript. 

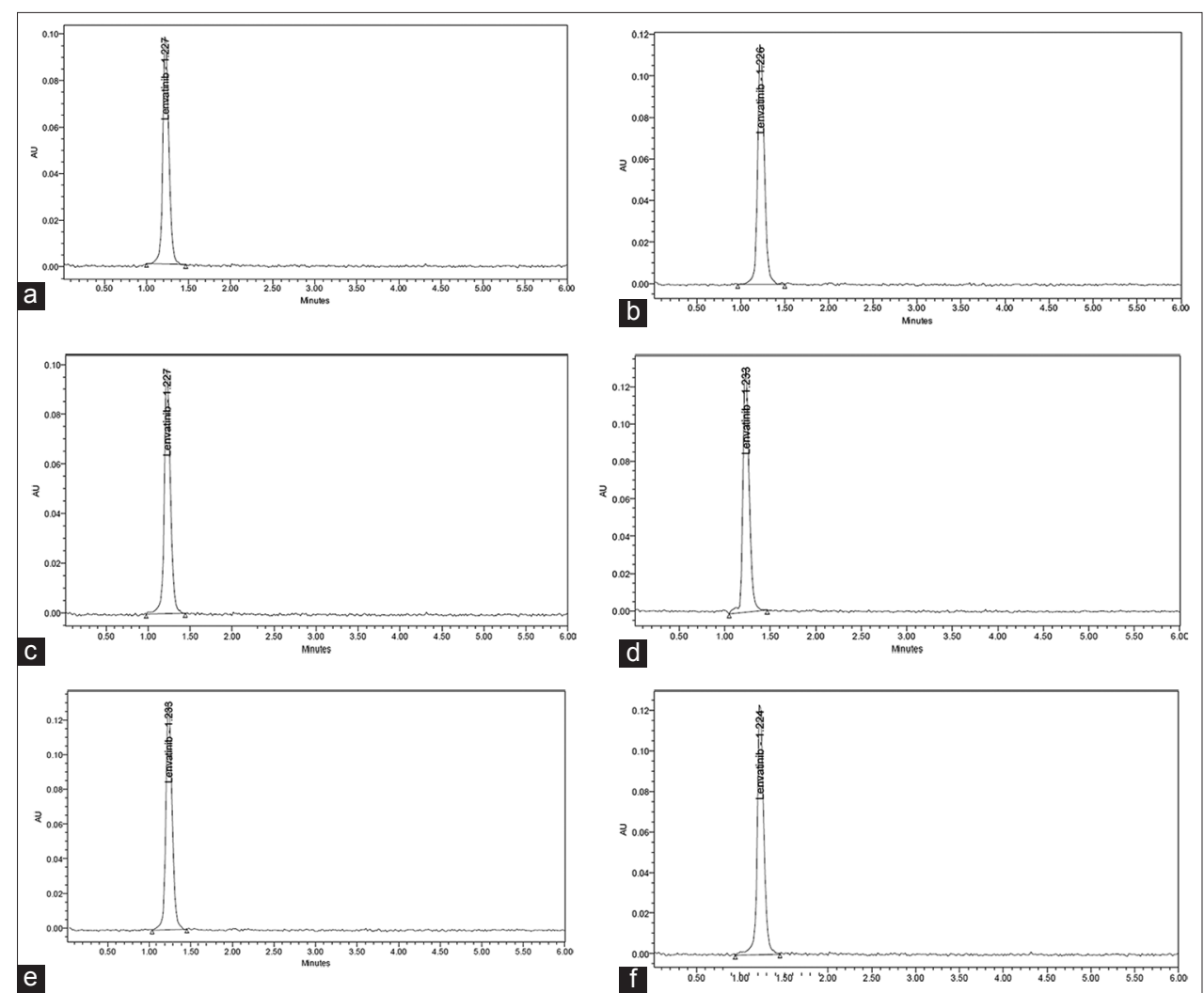

Fig. 6: (a) Ultra performance liquid chromatography (UPLC) chromatogram of acid-treated sample, (b) UPLC chromatogram of basetreated sample, (c) UPLC chromatogram of peroxide-treated sample, (d) UPLC chromatogram of water-treated sample, (e) UPLC chromatogram of ultraviolet light-treated sample, (f) UPLC chromatogram of heat-treated sample

\section{CONFLICTS OF INTEREST}

The authors state that they have no conflicts of interest. It has not meant published elsewhere. Moreover, it has not been simultaneously presented for publication elsewhere. All authors have agreed to the submission to the journal.

\section{REFERENCES}

1. Schlumberger M, Tahara M, Wirth LJ, Robinson B, Brose MS, Elisei R, et al. Lenvatinib versus placebo in radioiodine-refractory thyroid cancer. N Engl J Med 2015;372:621-30.

2. Cabanillas ME, Schlumberger M, Jarzab B, Martins RG, Pacini F, Robinson B, et al. A phase 2 trial of lenvatinib (E7080) in advanced, progressive, radioiodine-refractory, differentiated thyroid cancer: A clinical outcomes and biomarker assessment. Cancer 2015;121:2749-56

3. Krajewska J, Kukulska A, Jarzab B. Drug safety evaluation of lenvatinib for thyroid cancer. Expert Opin Drug Saf 2015;14:1935-43.

4. Cabanillas ME, Habra MA. Lenvatinib: Role in thyroid cancer and other solid tumors. Cancer Treat Rev 2016;42:47-55.

5. Matsui J, Funahashi Y, Uenaka T, Watanabe T, Tsuruoka A, Asada M. Multi-kinase inhibitor E7080 suppresses lymph node and lung metastases of human mammary breast tumor MDA-MB-231 via inhibition of vascular endothelial growth factor-receptor (VEGF-R) 2 and VEGF-R3 kinase. Clin Cancer Res 2008;14:5459-65.

6. Krishnaphanisri P, Raja S. Development and validation of new RPUPLC method for the determination of Cefdinir in bulk and dosage form. Int J Pharm Pharm Sci 2018;10:178-84.

7. Chakravarthy VA, Sailaja BB, Kumar AP. Development and validation of a dissolution method for frovatriptan tablets by reversed phase UPLC. Int J Pharm Pharm Sci 2015;7:125-30.

8. Mule KL. Rapid analytical method for assay determination for prochlorperazine edisylate drug substances by ultra performance liquid chromatography. Int J Curr Pharm Res 2017;9:118-22.

9. Prashanthi Y, Ahmed MA, Vijaya K, Riyazuddin Md. Method development and validation of lenvatinib drug by RP-HPLC in pharmaceutical drug dosage form. Indo Am J Pharm Sci 2016;3:1078-85.

10. Panigrahy UP, Reddy AS. A novel validated RP-HPLC-DAD method for the estimation of lenvatinib mesylate in bulk and pharmaceutical dosage form. J Chem Pharm Res 2015;7:872-81.

11. Shaikh A. Method development and validation of lenvatinib by HPLC and UV-Spectroscopy. Indian Drugs 2018;55:39-47.

12. Srikanth I, Rani AP. Development and validation of liquid chromatography coupled with tandem mass spectrometry method for estimation of lenvatinib in human plasma. Asian J Pharm Clin Res 2017;10:120-6.

13. Ogawa-Morita T, Sano Y, Okano T, Fujii H, Tahara M, Yamaguchi M, et al. Validation of a liquid chromatography-tandem mass spectrometric assay for quantitative analysis of lenvatinib in human plasma. Int J Anal Chem 2017;2017:1-6.

14. Mano Y, Kusano K. A validated LC-MS/MS method of total and unbound lenvatinib quantification in human serum for protein binding studies by equilibrium dialysis. J Pharm Biomed Anal 2015;114:82-7.

15. ICH. ICH: Q2 (R1), Validation of Analytical Procedures: Text and Methodology; 2005.

16. Bandla J, Ganapaty S. Stability indicating UPLC method development and validation for the determination of crizotinib in pharmaceutical dosage forms. Int J Pharm Sci Res 2018;9:1000-6. 